\title{
OVERVÅGNING SOM LOVGIVNING HASAN ELAHI OG SURVEILLANCE CAMERA PLAYERS SOM EKSEMPEL
}

\author{
"The Age of Imbalance is now upon us" \\ Paul Virilio, "The Media Coup de Etat", \\ i Le Monde diplomatique, 1. maj, 1994
}

Overvågning er en almennyttig foranstaltning, som beskytter os mod ydre og indre fjender. Der er imidlertid grund til at overveje overvågningens omfang, form og effekt. Hvad angår det første, er der ingen tvivl om, at omfanget er steget væsentligt i mange vestlige lande siden 9/11 2001. For nogle er der tale om en nødvendig udvikling, for andre er der tale om en uhensigtsmæssig stor vækst, som nu truer værdigrundlaget i det samfund, som skulle beskyttes. I denne artikel vil der imidlertid primært blive lagt vægt på form og effekt, især sådan som disse kommer til udtryk og reflekteres i kunsten. Med form tænkes således ikke kun på overvågningens faktiske form eller dens 'teknik', men også på den måde, overvågningsfænomenet reflekteres formmæssigt i aktuel kunst, dvs. hvilken medialitet og hvilke sansemæssige registre der anvendes, og hvilke synsvinkler og fortolkningsmuligheder der aktiveres. Overvågningen kan ikke vurderes som isoleret fænomen, som det ellers tit er tilfældet i diskussioner for og imod overvågning, men må anskues i relation til den situation, inden for hvilken den finder sted. Kunsten er eminent til at illustrere dette, eftersom den altid viser overvågning i en form for iscenesættelse, der afslører en række udsigelses- og fortolkningsniveauer.

Jeg har i denne artikel valgt at se på to nyere kunstværker, der begge spiller på George Orwells centrale bog 1984, som de refererer til i værktitlerne. Det drejer sig om Hasan M. Elahis værk Tracking Transience: The Orwell Project fra 2002 og The Camera Surveillance Players' værk 1984 fra 1998. De refererer begge til Orwell, men forskyder samtidig Orwells forståelse og repræsentation af overvågning ironisk ud i en langt mere vidtrækkende betydning. I denne forskydning viser værkerne, at overvågning, som måske umiddelbart kan synes at være et ekstra-kunstnerisk tema, i virkeligheden spiller godt sammen med kunstneriske strategier, ikke mindst fordi overvågning i princippet involverer flere synsvinkler og refleksionsmuligheder i sig. Overvågning implicerer som minimum en overvåget og en overvågende. Når dette iscenesættes i kunsten, tilføjes desuden tilskuerens niveau, som er niveauet for iagttagelse og fortolkning. Denne basale niveaudeling kan udnyttes til at nuancere 
forståelsen af, hvad overvågning er for noget. Den kan yderligere kompliceres ved at installere flere overvågede eller overvågende, eller flere synsvinkler for forståelsen af det overvågede. I stedet for at blive et symptom på en totaliserende tænkning (som overvågning er i Orwells værk) bliver overvågningsfænomenet i den nyere kunsts iscenesættelse et værktøj til at transformere vores refleksioner over nogle af de mekanismer, der ligger til grund for overvågningen, og nogle af de effekter, overvågningen har. De to værker har det tilfælles, at de tester eller kommenterer etiske implikationer af overvågning.

For at forstå effekten af overvågning - og for at forstå kunstens refleksion af overvågningsfænomenet - er det imidlertid nødvendigt at se dette i relation til en generel samfundsudvikling. Og her er det vigtigt ikke kun at relatere overvågningsfænomenet til 9/11. Det er selvfølgelig utvetydigt, at denne begivenhed har betydet meget for væksten i overvågning og direkte har fremprovokeret gennemførelsen af en række liberaliseringer af overvågningslovgivning i mange lande, fx USA, England og Danmark. ${ }^{1}$ Disse lovændringer har mange steder været meget radikale, og kritikere og menneskerettighedsforkæmpere, f.eks. i USA, har direkte kaldt lovændringerne forfatningsstridige.

For at forklare, at så radikale ændringer overhovedet har kunnet gennemføres, refererer lovgivere og teoretikere igen og igen til den sikkerhedspolitiske ustabile situation som noget, der har nødvendiggjort tiltagene. Timothy Druckney hævder, at kun et øjeblik af irrationel panik (panicked unreason) kan have muliggjort, at politikere i USA fra et bredt politisk spektrum underskrev så radikale love som $\mathrm{fx}$ The USA Patriot Act (fra oktober 2001) og The Military Order (fra november 2001). (Druckney 152).

1 Allerede d. 26. oktober 2001 - ikke mere end en måned efter angrebet på World Trade Center - underskrev George Bush "The USA Patriot Act" (USA Patriot Act: akronym for "Uniting and Strengthening America by Providing Appropriate Tools Required to Intercept and Obstruct Terrorism Act") hvis formål var følgende: "At forene og styrke USA ved at facilitere de nødvendige redskaber for at hindre og obstruere terrorisme.” Denne lov, som omfatter mere end hundrede enkeltlove, giver politiet udstrakte rettigheder til overvågning, aflytning af telefoner og overvågning af anden kommunikation, fx e-mail korrespondance, ransagning af hjem uden dommerkendelser, overvågning af finansielle transaktioner, bankkonti, sundhedsoplysninger, dna-oplysninger mv. og en lettelse af reglerne for tilbageholdelse af mistænkelige immigranter. Loven udvider også forståelsen af terrorisme til at inkludere hjemlige 'terror'-angreb. Senere fulgte The Military Order af November 13, 2001, som havde underteksten "Tilbageholdelse, behandling af og retssager mod visse ikke-statsborgere (non-citizens) i krigen mod terrorisme”. Denne lov stadfæstede, at sager mod terror-mistænkte skulle føres for en militær domstol, og at de mistænkte kunne tilbageholdes på ubestemt tid. Man begrundede denne lov med den undtagelsestilstand som 9/11 havde ført med sig. I både England og Danmark er der sket en stærk liberalisering af lovene om overvågning. Også det engelske og det danske efterretningsvæsen har nu øget mulighed for at undersøge mistænkte uden dommerkendelse, herunder at aflytte telefoner, checke e-mailkommunikation, ransage private hjem samt øgede muligheder for offentlig overvågning med kameraer og identitetskontrol. En undersøgelse udført af Privacy International kalder Danmark for et Extensive Surveillance Society. Denne 'ranking' er lavet d. 28. 12, 2007 og kan ses på følgende hjemmeside: http://www.privacyinternational.org/article. $\underline{\text { shtml? } \mathrm{cmd}}[347]=x-347-559597$, Der skelnes her mellem syv niveauer for overvågning, "Extensive surveillance society"er niveau 6 lige før det højeste niveau: "endemic surveillance societies”, som bla. inkluderer Rusland, Kina, USA og England. 31. maj, 2010. Privacy International har også lavet en oversigtsrapport over lovændringer i Danmark fra 2000-2007, ændringer, der har øget overvågningen på en række områder, se: http://www. privacyinternational.org/article.shtml?cmd[347] $=x-347-559545,31$. maj, 2010. 
Radikaliteten af de nye love må selvfølgelig forstås som en reaktion på terroren. Den er til en vis grad legitimeret af risikoen for terror, men det ville være en fejl at forstå overvågningstendensen bare som et øjeblik af “irrationel panik". Hvis dette var tilfældet, skulle lovene være blevet ændret efterlods, og dette er, trods ihærdige forsøg fra kritikere, kun sket i moderat omfang.

Overvågningslovene bør snarere forstås som et særligt radikalt symptom på en meget længere udvikling af kontrolsamfundet. Overvågning er ikke en undtagelse, men er efterhånden blevet en regel inden for mange af de områder, hvor mange tidligere ville have kæmpet imod den i den individuelle friheds navn. Det gælder fx sundhedsovervågning, sammenføring af registre, arbejdsovervågning, kameraer ved boligblokke og i butikker, elektronisk markeds- og kundeovervågning etc. Overvågning er ikke en rest af et fortidigt, lukket og bureaukratisk totalitært samfund, men er en del af den åbne og moderne medievirkelighed, vi færdes i. Dermed kan overvågningsfænomenet heller ikke forklares med reference til én årsag, men må ses i et langt bredere perspektiv.

De to værker, jeg har valgt, reflekterer kun den 'sikkerhedspolitiske' overvågning, men selv når man kun iagttager denne del af overvågningen, må mange traditionelle opfattelser vige for mere dynamiske. Juristen Larry Catá Backer har i en tankevækkende artikel med titlen "Global panopticism” foreslået, at den nye transnationale overvågning ikke bare skal forstås som et symptom på forskellige nationale sikkerhedspolitiske tiltag og heller ikke blot som produkt af den lovgivning, der er opstået af sikkerhedspolitiske hensyn, men at overvågningen har selvstændiggjort sig og som regulativ styringsmekanisme er blevet sin egen lov, som dermed erstatter den lovgivning, som den skulle være underlagt. Hvis det er rigtigt, øges vigtigheden af ikke kun at se på overvågning som en særlig teknik eller beskyttelsesforanstaltning, men at se den som en generaliseret funktion af den komplekse samfundsmæssige kontekst, den indgår i.

\section{Surveillant assemblage}

For at forstå moderne overvågning som fænomen har mange teoretikere refereret til Michel Foucault og det begreb, han meget succesrigt lånte fra Jeremy Benthams opfindelse fra det 18. århundrede, nemlig begrebet panoptikon. Selv om det er blevet udsat for en hård kritik for dets manglende evne til at omfatte den moderne virkelighed, så er det næsten umuligt at aflive panoptikon-begrebet. (Lyon, Theorizing Surveillance: 3-4). Grunden til dette er, at Foucaults udlægning af panoptikonet samler en række af de centrale karakteristika i en overskuelig, forståelig form.

Panoptikonet som overvågningsform gør det muligt at differentiere massen og overvåge det enkelte individ inden for et afgrænset område. Panoptikonet refererer til arkitekturen $i$ hele den bygning, det omfatter, men et vigtigt element i denne er det centrale overvågningstårn, som er synligt fra alle hjørner af bygningen. Det er en afgørende pointe, at det individ, der overvåges, ikke ved, hvornår det bliver overvåget, og om der overhovedet er nogen mennesker i tårnet. Herved opnås en 
integration af overvågningsfunktionen i det enkelte menneske som en selvdisciplinering, der har en langt større effekt end selve tårnet, som det imidlertid ikke kan være foruden. Panoptikonet er derfor karakteriseret af tre ting: total synlighed af den overvågede, usynlighed af de overvågende, og et samspil mellem den ydre, tekniske overvågningsmaskine og den internaliserede overvågning i det enkelte individ.

Der er en del af disse træk, der også går igen i moderne overvågningsteknik, men den store svaghed ved panoptikonmodellen er, at den er afhængig af muligheden for at isolere dem, der overvåges inden for et afgrænset område. Panoptikonet er baseret på en disciplineringsmodel, der er udviklet i et disciplinært samfund med en forholdsvis gennemskuelig hierarkisk struktur og et klart juridisk-politisk styringspotentiale.

Spørgsmålet er imidlertid, om vi stadig lever i et sådant samfund, og om panoptikonmodellen kan fungere som forståelsesramme for moderne overvågningsstrategier. Der er i hvert fald tre aspekter af udviklingen, der peger i andre retninger: globaliseringen, teknikken og afhierarkiseringen af overvågningen. Globaliseringen betyder øget mobilitet og transnationale udvekslinger, som er vanskelige at afgrænse og overvåge, teknikken har udviklet sig i en række forskelligartede retninger, der både baserer sig på synlighed (overvågningsapparater) og usynlighed (f.eks. dataregistrering mv.), og endelig er der meget overvågning, som ikke kommer fra en statslig magtenhed, men derimod fra private aktører og selskaber, der trods det, at de er sanktioneret af statslig lovgivning, følger private og forskelligartede interesser. Med et udtryk af Kevin D. Haggerty og Richard Ericson bør man måske snarere tale om en surveillant assemblage end om én singulær overvågning (Haggerty/Ericson 172).

Overvågningen har dermed undergået en udvikling, som nødvendiggør en fornyet undersøgelse af de grundlæggende mekanismer i overvågningssituationen, og som ikke bare isolerer disse til tekniske spørgsmål, men ser dem i sammenhæng med samfundsudviklingen siden murens fald eller ca. de sidste 50 år.

Ifølge Gilles Deleuze forandrede tingene sig allerede efter 2. verdenskrig, hvor vi ophørte med at leve i disciplinærsamfund og i stedet begyndte at leve i kontrolsamfund. Ifølge Deleuze baserede disciplinærsamfundet sig på muligheden for afgrænsning og forståelsen af individets formning (mold) ud fra dets plads i systemet; kontrolsamfundet er derimod ifølge Deleuze baseret på dynamiske formninger (modulations):

"Indespærringerne er adskilte former, støbeforme, kontrolmekanismerne er derimod en modulation som en slags selvformende støbeform, der konstant ændrer sig fra det ene øjeblik til det andet - eller som en sigte, hvis masker ændrer sig fra et punkt til et andet.” (Deleuze: 214)

Og han fortsætter senere i samme tekst:

"I kontrolsamfundet [...] er det væsentlige ikke længere en underskrift eller et tal, men et ciffer, for cifferet er en adgangskode, hvorimod disciplinærsamfundet reguleres 
af befalingsord (såvel fra det samfundsskabendes som fra modstandens synsvinkel). Kontrollens numeriske sprog udgøres af cifre, der giver adgang eller formener adgang til information.” (Deleuze: 215).

I et samfund, der er baseret på mobilitet, er det afgørende, at kontrollen kan udøves på afstand, uafhængig af situering og i en interaktiv dialog. At der ikke er forudbestemte regler, betyder ikke, at bevægelser kan foregå frit og uhindret, men det betyder, at der kan opstå en forhandlingssituation omkring reglerne, at reglerne skabes fremadrettet. Det enkelte individ er således ikke kun en brik, der skal indreguleres $i$ et allerede prædisponeret system, men kan ideelt eller potentielt være med til at påvirke selve det styrende system, - hvis det vel at mærke kan forholde sig til den kodede verden, som det agerer i. I det traditionelle disciplinære samfund var det afgørende at lokalisere og overvåge det enkelte individ og at kunne bestemme dets kategori inden for massen. Ifølge Deleuze holder den skelnen, man traditionelt har lavet mellem masse og individ, ikke i det nye samfund, og han foreslår begrebet dividual til at betegne det nye 'individ'. Individet godkendes ikke som en bestemt form, men i form af nogle konkrete egenskaber og handlinger inden for et kodet system. Man kan måske sige, at man bevæger sig fra at overvåge substans til at overvåge kodede bevægelser.

Som det fremgår af citatet fra Deleuze, er der imidlertid også en instans, der har magten til at tillade eller nægte adgang til information. Magten er stadig en del af overvågningssystemet. At den ikke længere synliggøres af et stort tårn, er et symptom på, at samfundet ikke er disciplinært, men markedsstyret og bevægeligt, orienteret mod kognitive værdier og ekstremt påvirkelige kursbevægelser frem for mod produktion og ejerskab.

Deleuzes analyse er baseret på et moderne og dynamisk samfundssyn. Ser man imidlertid på den konkrete overvågning, der finder sted i den vestlige verden $\mathrm{i}$ dag, passer den kun delvist til et sådant dynamisk samfundssyn. Selv om mange nye former for overvågning ikke er knyttet til en fysisk iagttagelse eller en ordensmæssig stabil registrering, men er lige så mobil som 'livet selv', så kan man også registrere, at gamle overvågningsformer, f.eks. almindelige overvågningskameraer på åbne pladser og i lukkede rum, som f.eks. lufthavne, togstationer, butikker mv. har fået en fornyet renæssance. Desuden kan man også hævde, at selv nogle af de nye former for overvågning, dna-registrering, iris-aflæsning, mobil-telefonaflytning mv. er teknisk set langt mere sofistikerede end overvågningstårnet i det gamle panoptikon, så følger de på visse punkter gamle overvågningslogikker: de forsøger stadig at fastholde, registrere, nummerere og ordne, som om vi stadig levede i det disciplinære samfund. Og selv om der er masser af privatiseret og forskelligartet overvågning, så bekræfter selve overvågningslovene den længsel efter absolut magt og synlighed, som det gamle panoptikon inkarnerede. Overvågningslovene arbejder på at udvide 'afgrænsningsstederne', men arbejder grundlæggende inden for en 'afgrænsningsmodel'.

På den måde synes overvågningsfænomenet at være fanget mellem to logikker 
eller mellem to historiske modeller for overvågning, som umiddelbart synes modstridende. Det er vigtigt at erkende både, at der er reminiscenser af den disciplinære logik, som fungerer som en aktiv del af samtiden, og at der samtidig er nye overvågningslogikker, der måske er ved at overtage de gamle.

Overvågningsfænomenet som sådan er ikke i modsætning til eller en tilfældig biomstændighed ved det moderne samfund, men en nødvendig del af selve informationssamfundets organisationsform. Som løsrevne 'værdier' er frihed/mobilitet og overvågning/kontrol modsætninger, men i den senmoderne virkelighed er de integrerede mekanismer i den samme orden. Spørgsmålet er imidlertid, hvilken form overvågningsfænomenet antager, og hvilken logik det følger. For at forstå den kompleksitet og sammensathed af usamtidige logikker, der er i overvågningsfænomenet, kan man med fordel kigge på kunstens kritiske refleksion af dette.

Mens overvågning som kontrolstrategi har som formål at afsløre mest muligt, give mest mulig information og/eller nå til opklaring af enhver mistænkelig handling, så har kunsten, når den ser på overvågningen, været optaget af spændingsfeltet mellem synlighed og usynlighed, mellem afsløring og hemmelighed, hvilket har givet overvågningstemaet en umiddelbar kompleksitet, der sætter spørgsmålstegn ved selve overvågningens karakter. I 1984 søger Winston Smith hele tiden at gøre sig usynlig for overvågningskameraerne, placere sig i deres blinde vinkler og opsøge 'hemmelige' rum, hvor han mener at kunne være i fred. I både Elahis værk og i The Camera Surveillance Players' værk arbejdes der derimod med synlighed som modstrategi, men på to forskellige måder.

\section{Hasan M. Elahi: "Tracking Transience: The Orwell Project"}

Hasan M. Elahi, som er ansat ved laboratoriet for nye medier ved School of Art and Design ved San José State University i Californien, kommer oprindeligt fra Bangladesh. Elahi blev anholdt i Detroit lufthavn i juni 2002 efter en rejse til Afrika, mistænkt for at være relateret til terrorvirksomhed. Gennem seks måneder blev han jævnligt afhørt af FBI om, hvor han var i september 2001 (især d. 12. september 2001), og FBI undersøgte også Elahis liv generelt og afhørte hans kone og kolleger. For ikke at blive anholdt igen begyndte han at checke ind ved FBI, hver gang han skulle ud at rejse. Senere gjorde han hele sit liv tilgængeligt på nettet og hævdede hermed at hjælpe FBI med arbejdet. Samtidig skabte han imidlertid et tankevækkende kunstværk, som siden har været udstillet på udstillinger, og som konstant kan ses på nettet (http://trackingtransience.net/) $)^{2}$

På websiden kan man se, hvor Hasan Elahi befinder sig døgnets 24 timer hele året rundt. Man kan se alle de måltider, han indtager, og alle de toiletter, han besøger. Man kan se lufthavne, toge og bygninger, bankdokumenter og boner fra butikker og lign. I et interview forklarer Elahi, at websiden er hans alibi. Selv om han nu er uden for mistanke for den oprindelige anklage, så betragter han websiden som en

2 Se også Peter Lauritsens artikel tidligere i dette nummer. 
fremtidssikring. Ingen kan nu anklage ham for at være et sted, han ikke har været. Den maksimale sikkerhed er således ikke forbundet med usynlighed eller evnen til at gemme sig for overvågningskameraerne eller efterretningsvæsenet, men med absolut synlighed. Elahi vender ikke bare magtens blik (sousveillance), men efterligner, parodierer og omvender overvågningens indre logik. Derved fungerer hans værk både som et slags overvågningslaboratorium, hvor han afprøver overvågningsstrategier, og som et metarefleksivt rum over overvågning.

Der er særligt fire aspekter af overvågning, som værket kaster et interessant lys over, nemlig overvågningens rækkevidde, den bagvedliggende systematik og styring af overvågningen, den overvågedes retsstatus samt overvågningens mediale virkelighed og æstetiske strategier.

På grund af sit arbejde som forsker i medier og kunstner rejser Elahi meget. Han er et grænseoverskridende individ, som ikke kan afgrænses inden for et system. Grunden til, at han blev mistænkelig i FBI's øjne, var, at ejerne af en række lagercontainere rapporterede, at Elahi var arabisk, at han havde sprængstoffer i en af deres containere, og han var flygtet $d$. 12. september. Alle oplysninger i deres rapportering er forkerte. Elahi havde ikke sprængstoffer i sin container, han er ikke arabisk, og hans rejse var ikke en flugt, men en forretningsrejse. Han blev mistænkelig, fordi han så 'anderledes' eller arabisk ud, og fordi han rejste meget.

Denne første anklage var, som man kan se, ikke baseret på FBIs egen overvågning, men på oplysninger fra private agenter. Det er vigtigt at understrege, at et af overvågningens nyere træk er, at den ikke kun foregår på initiativ af en statslig instans, men at den kan foregå overalt, også med private og personlige aktører. Det er det, man noget eufemistisk kan kalde "overvågningens demokratisering". Det afgørende også i disse tilfælde er imidlertid, hvem der i sidste instans samler oplysningerne og har magt til at fortolke dem og handle ud fra disse. FBI valgte selv at tillægge Elahis profil betydning.

At det i Elahis tilfælde var FBI, der stod for behandlingen, placerer i en vis forstand Elahi i samme position som Winston i 1984, dvs. som et enkelt frit, mobilt individ over for en statslig sanktioneret kontrollerende og disciplinerende institution. Modsat Winston, fremstår Elahi imidlertid ikke som et mærkeligt særtilfælde. Tværtimod inkarnerer han en moderne global virkelighed med en ideelt set ubegrænset bevægelighed for individet, og at et moderne overvågningssystem ikke kan tackle og fortolke denne virkelighed rigtigt, er et stort problem for overvågningssystemet i sig selv.

Et andet problem, der synliggøres gennem Elahis værk, er individets manglende retssikkerhed over for overvågningssystemerne. Elahi blev mistænkt for terrorisme, men han blev aldrig direkte anklaget for noget. Da FBI efter 6 måneders jævnlige afhøringer og flere løgnedetektor-tests ikke kunne finde beviser for terrorvirksomhed, bad Elahi om at få et dokument, der frikendte ham. Det kunne FBI ikke give ham, da han jo ikke var anklaget for noget. I stedet anbefalede de, at han kontaktede en af deres agenter, hver gang han skulle ud at rejse, så han ikke ville blive udsat for deres mistanke igen. Overvågningssystemet placerer dermed Elahi 
i en mellemposition: han er ikke skyldig, men han er heller ikke frikendt. Sagen er blot indtil videre indstillet pga. "bevisets stilling", kunne man sige.

Elahis sag er et radikalt tilfælde, men i princippet sætter en hvilken som helst overvågning det overvågede individ i en tilsvarende position. Selv om man ved, at man er uskyldig, så kan man på den anden side ikke være helt sikker, for i de fleste tilfælde kender man ikke overvågningens kriterier for mistænkelighed. Ifølge Elahi så mislykkedes FBIs fortsatte forsøg på at få ham til at passe ind i kategorien "arabisk terrorist" ikke, fordi han modsatte sig denne beskrivelse, men kun fordi han samarbejdede med FBI. Ifølge journalisten Ethan Zuckerman

"[...]følte [Elahi] afgjort, at der var en trussel om ubegrænset tilbageholdelse, og han tror, at den eneste ting, der reddede ham, var en fælles kultur - evnen til at citere tekster fra folkesange eller tale om college fodbold, den slags ting, som en terrorist ville have svært ved at fake."

I begyndelsen, hævder Elahi, var hans samarbejde med FBI en ren overlevelsesstrategi. Senere blev det til en kunstnerisk strategi, som skulle afsløre overvågningsmekanismerne ikke bare hos FBI, men i det kontrolsamfund, vi lever i.

Ser man på de kunstneriske strategier, som Elahi anvender i sit værk Tracking Transience, så er det tydeligt, at Elahi mimer FBI's dokumentations 'begær', men han gør det på en måde, som giver dokumentarisk information den nøjagtig modsatte status af, hvad den har for FBI. Eller formuleret på en anden måde: værket peger på uoverensstemmelsen mellem den status, som dokumentarisk information ideelt og reelt set har for FBI. Ideelt får FBI betydningsfuld information om virkelige forbrydere, reelt får de millioner af informationer, hvoraf kun en mikrodel er anvendelig. På Elahis hjemmeside eksisterer den samme dobbelthed.

Hvert eneste pedantiske fotografiske billede tjener selvfølgelig én overordnet funktion: at dokumentere, hvor Elahi befinder sig, men der er et misforhold mellem denne potentielt betydningsfulde oplysning og det overload af information, som hjemmesiden giver. De hundredvis af billeder af nudler og ris-måltider, der er afbilledet på hjemmesiden, sandsynliggør selvfølgelig, at Elahi har været de steder, hvor måltiderne er købt, men dette kunne have været dokumenteret meget enklere og mere overbevisende f.eks. med kopier af hotelregninger, eller han kunne have nøjedes med kopier af bon'er eller lign.

Fotoerne af måltiderne betyder kun noget i kraft af deres ikke betydning, og det er derfor ironisk, at de manifesterer sig så massivt på hjemmesiden som et

3 Refereret af Ethan Zuckerman i "Tracking Hasan Elahi” 19. okt, 2006. Zuckerman refererer et foredrag med Hasan Elahi. Efter foredraget blev Elahi spurgt, om FBI virkelig truede med Guantanamo, eller om hans kunstneriske temperament måske havde overdrevet situationens alvor. Elahi kommer derefter, ifølge Zuckerman med den beskrevne reaktion.: "Elahi explains that it was never made concrete, but that he certainly felt the threat of indefinite detention, and that he believes the only thing that saved him was a common culture - the ability to quote the lyrics of country songs, or talk about college football, the sort of things a terrorist would find very hard to fake", www.worldchanging.com/arhcives/005105,html, 27. maj 2010. 

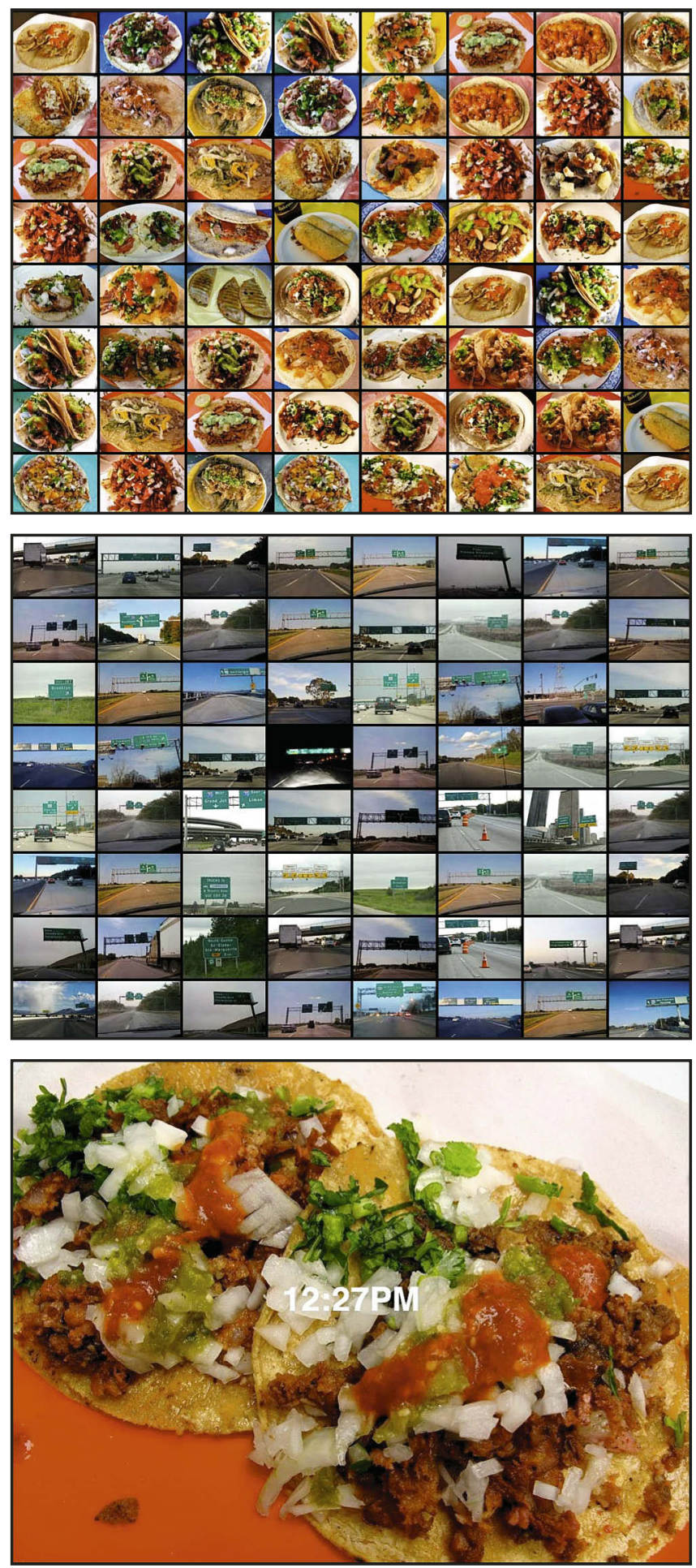

Figur 1: “Et væg-

til-væg tæppe af måltider", Hasan

Elahi. "Tracking

Transience"

Figur 2: "Anonyme motorveje", Hasan

Elahi. Tracking

Transience
Figur 3: "Måltidet

er $\mathrm{k} ø \mathrm{bt} / \mathrm{indtaget}$

kl. $12.27 \mathrm{pm}$, men

hvor og hvilken dag?".

“Tracking Transience" 
gigantisk, farverigt væg-til-væg tæppe. Ligeledes er det med de andre billeder: billederne af motorveje, lufthavne, supermarkeder mv. Ser man én motorvej, vil man være interesseret $i$, hvad det er for én, og hvor den fører hen. Men ser man halvtreds billeder af motorveje samlet i ét billede bliver disse motorveje blot et billede på generel transit, og det er i øvrigt karakteristisk, at stort set alle de steder, der er fotograferet, er transitsteder eller anonyme steder som lufthavne, supermarkeder, tunneler, korridorer, tankstationer og parkeringspladser, og selv om sådanne steder tit anvendes som location i agentfilm, er de i Elahis version snarere ikke-steder og de bærer intet skjult løfte om handling.

Alligevel forsøger betragteren, nøjagtig ligesom FBI, at finde signifikans i den store mængde af enkeltobservationer. Et af værkets vellykkede effekter er, at betragteren, selv om man ved, det er et kunstværk, bliver fanget i et forsøg ikke bare på at lokalisere Elahi, men også på at finde mønstre i hans færden. Betragteren bliver dermed selv til overvåger. Og det er delvist pga hjemmesidens inviterende æstetik, som arbejder dels med et langsomt, nærgående panorerende kamera, som synes at nærme sig en afsløring af noget, dels med de flotte billedcollager, hvor enkeltbillederne kan forstørres op, som om det er helt afgørende at se en tallerken med ris i karry i close up.

Betragteren kan imidlertid ikke finde sådanne mønstre på Elahis webside. Man kan til enhver tid se, hvor han er i netop dét øjeblik, man trykker på curseren, men det er grundlæggende vanskeligt at få et overblik over og rekonstruere hans færden tilbage i tid. Dette hænger sammen med en bevidst strategi for websiden: mens hvert eneste øjeblik minutiøst er registreret med klokkeslæt og sted (inklusive GPSpositioner og markering på et verdenskort), så er selve billederne af de forskellige objekter ikke indsat kronologisk, årstallet er ikke markeret, og der er heller ikke andre overskuelige systematikker. Billederne er tværtimod kun samlet under temaer, sådan at alle måltiderne, alle transitstederne mv. er samlet hver for sig.

Det er desuden signifikant, at der ingen billeder er af Elahi selv. Man kan derfor reelt ikke vide, om han er på stedet, eller om han blot har overladt sin GPS til en kammerat. Og selv hvis han var på nogle af billederne, ville det være umuligt at vide, hvilket ærinde Elahi har på det givne sted. På denne måde parodierer hjemmesiden vores og overvågningssystemernes begær efter at finde ud af noget, og hvis den overhovedet viser noget, handler det mere om hverdagens tilfældighed og serielle uendelighed end om signifikans. I modsætning til overvågningens dybdelogik, der baserer sig på et princip om meningsfuldhed og transcendens, baserer Elahis hjemmeside sig modsat på meningsløshed og overfladisk horisontalitet.

\section{Sousveillance: Surveillance Camera Players}

Surveillance Camera Players' værk 1984 bruger en helt anden strategi end Elahi, en strategi, man kunne kalde sousveillance. Sousveillance er et begreb opfundet af Steve Mann, der kan forstås både bogstaveligt og overført: I stedet for at samfundet eller en politisk magt overvåger individet, overvåger individet samfundet. Steve Mann 
har konstrueret en række mobile kameraer, der kan monteres på et menneske, der således får mulighed for at udsætte andre og f.eks. magten selv for overvågning (Mann 531ff). Gruppen af Surveillance Camera Players (herefter SCP) består af en løst sammensat og skiftende gruppe af anarkister. Der er ingen professionelle skuespillere. Siden grundlæggelsen i 1996 har de opført en lang række performances foran overvågningskameraer. Alle performances har en dogme-agtig stil: de er bevidst primitive og består mestendels i at vise en række hjemmelavede plakater foran kameraerne suppleret med amatøragtig pantomime. Som hovedregel taler de ikke og bruger ikke anden lyd. Den lyd, der akkompagnerer stykket, er således den almindelige larm i det offentlige rum, som blender ind med stykket.

Hovedsigtet i SCP's aktioner er at protestere mod overvågningskameraer, som de mener, har en uhensigtsmæssig adfærdsregulerende effekt på befolkningen generelt, og som de desuden mener rammer socialt skævt. Kameraerne indfanger nemlig især de hjemløse og udskudte sociale eksistenser, som opholder sig i de offentlige transitsteder, som kameraerne overvåger. Desuden, hævder SCP, bruges kameraerne også til at overvåge politisk aktivisme. Som eksempel nævner en af deres talsmænd, Bill Browne, at der er opsat kameraer ved den katolske kirke St. Patricks Cathedral i New York, hvor der ikke er nogen kriminalitet, men hvor der har været en række politiske demonstrationer mod den katolske kirke. (Baumgärtel: 616).

1984 blev 'opført' i 1998 foran et overvågningskamera i metroen i New York. George Orwells værk 1984 er her transformeret til et skuespil i seks akter, som meget skitseagtigt viser hovedpassager fra romanen: Winston møder Julie, Winston møder Julie og Brian, Brian torturerer Winston, Brian skyder Winston. Stykket er 'akkompagneret' af plakater, der f.eks. viser et stort tegnet billede af Big Brother, en plakat, der viser kontradiktorisk newsspeak (War is peace, hate is love..) og en plakat, der viser den symbolske pyramide, som i USA har en særlig signifikans, eftersom netop dette symbol er trykt på en-dollarsedlerne, med en direkte henvisning til den amerikanske forfatning. Wilson og Julie bærer skilte med numre, som om de var fanger. To gange i skuespillet viser de en plakat, hvor der står "We are the dead". Der er desuden en 'fortæller', en mand med hvid dødningemaske, som styrer skuespillet: han viser Big Brother-plakaterne i baggrunden og fremviser skilte med de skiftende akter.

Performancen er et eksempel på sousveillance eller, som de selv hævder, på situationistisk detournement. Ifølge SCP selv ødelægger deres performance ikke overvågningskameraernes spektakel (spectacle), men vender det mod dem selv. Den kritiske performance er således grundlæggende refleksiv i sin karakter. Spillerne er placeret under et videokamera på metrostationen og kigger hele tiden ind i dette kamera og f.eks. ikke på de forbipasserende. De bliver filmet både af overvågningskameraet og af andre SCP-spillere, der filmer den monitor på stationen, der viser overvågningskameraets optagelser. På et tidspunkt bevæger nogle af SCP-folkene sig ind i det kontor, hvor de overvågende politifolk sidder, og her filmer de både politifolkene (dog kun meget lidt) og den monitor, som politikfolkene har på kontoret, som viser SCP's performance. 

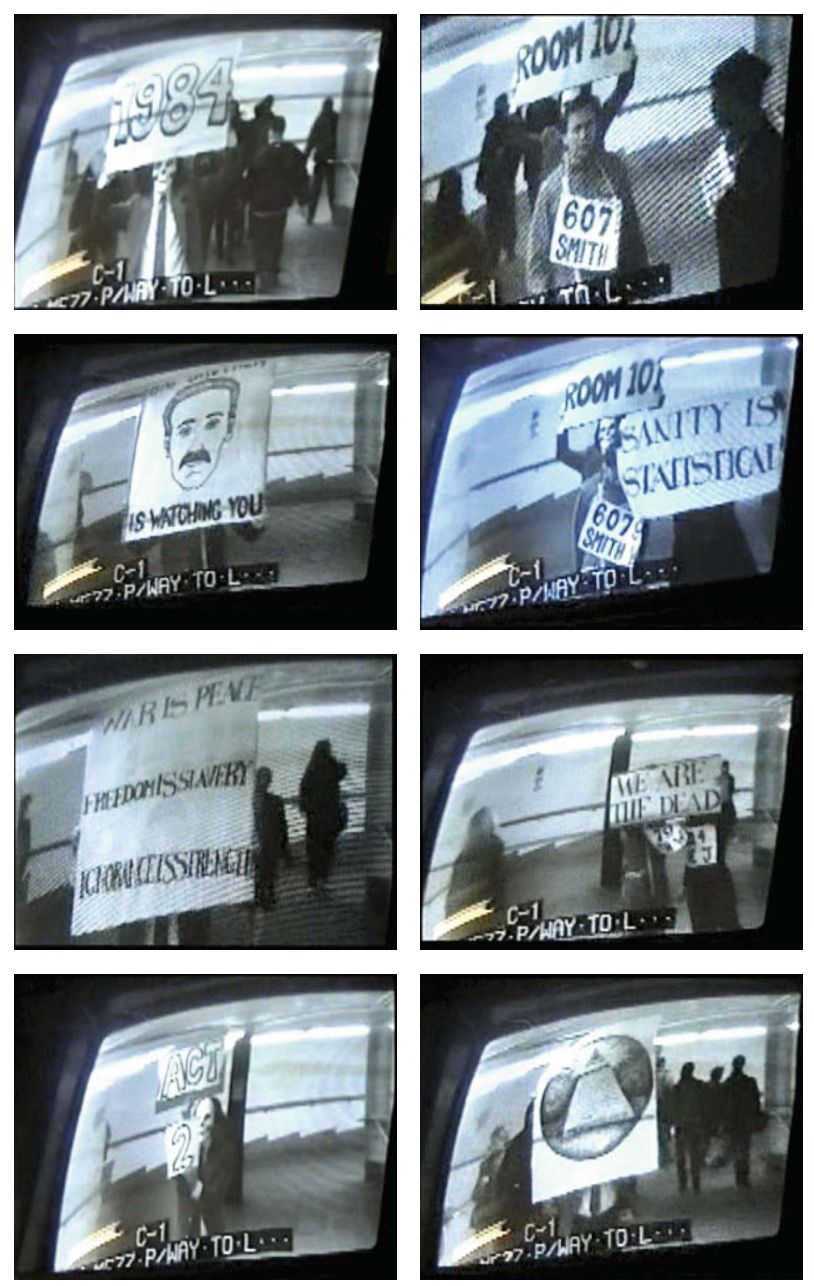

Figur 4-11: “"1984” af Surveillance Camera Players. Et værk, der er inspireret af George Orwells roman 1984".

Dermed dokumenterer SCP-folkene både teaterstykket på metrostationen, overvågningskameraet på stationen og overvågningens åsted. Samtidig dokumenterer de også receptionen af deres teaterstykke. På det videoklip, der ligger på nettet, hører man et par kommentarer fra én af de politimænd, der overvåger metroen. Han er først meget undrende over, hvad der foregår, spørger så, om de har en tilladelse til at optræde, men ender med at betragte det hele som en ufarlig vittighed. Da en af SCP-folkene forklarer politimanden, at deres stykke skal gøre folk opmærksom på, at overvågningen finder sted, er politimanden himmelfalden: "But they know that already!” De forbipasserende, som man kan se på videoen, standser ikke op, men kaster hurtige og undrende blikke i retning af truppen. 
Ligesom anden performancekunst rejser også dette værk et spørgsmål om værkets grænser. Er værket teaterstykket, eller er værket den video, der dokumenterer teaterstykket, situationen omkring teaterstykket og receptionen på teaterstykket. Jeg vil i denne sammenhæng vælge det sidste, og det betyder, at værkets reception ikke kun skal vurderes ud fra politimandens og de forbipasserendes reaktion, men skal vurderes ud fra receptionen af den video, der ligger på nettet.

Værket bliver dermed en meget kompleks størrelse, der har adskillige metaniveauer i sig. Det interessante ved værket knytter sig ikke så meget til selve performancen eller det budskab, de udsiger gennem performancen, men til de mange metaniveauer, som den er indlejret i. Værket udstiller grundlæggende overvågning som en multidimensionel begivenhed. Overvågning er noget, man underlægges, men det er også noget, man selv kan foretage sig.

De mange metaniveauer gør det også vanskeligere at afkode, hvordan værket forholder sig til George Orwells roman. Det kan anskues som en parodisk vending på romanen, men det kan også anskues som et værk, der trækker på Orwell på en anerkendende måde og for at påpege totalitaristiske aspekter af den aktuelle overvågning. I begge tilfælde får værket på en ret radikal måde rejst nogle fundamentale spørgsmål om overvågningens karakter i dag. Har overvågningen karaktertræk tilfælles med BigBrother, eller må man forstå SCP's aktion som en avantgardistisk forskydning af hele problemfeltet?

\section{Juridiske komplikationer}

Ligesom situationisterne er SCP generelt kritiske over for konsumsamfundet. Dette understreges af den konstante visning af den symbolske magtpyramide, der kendes fra endollarsedlerne. Således kobles politisk og økonomisk magt. Lige så vigtigt er det imidlertid, at der i pyramidesymbolet er en direkte henvisning til den amerikanske forfatning. Der peges dermed direkte på overågningskameraernes potentielle trussel over for det enkelte individs retssikkerhed.

I det ovenfornævnte interview hævder Bill Browne, at brugen af overvågningskameraer er en overtrædelse af paragraf 4 (4th Amendment) i forfatningen. ${ }^{4}$ Det er den paragraf, der beskytter mod urimelig indgriben og ransagning af private hjem, og han tilføjer, at performancen også er inspireret af højesterets afgørelse i sagen Katz mod USA fra 1967. Selvom der er sket meget i amerikansk lovgivning siden, så er det alligevel interessant at inddrage konklusionerne fra denne sag. Charles Katz blev dømt for ulovligt spil, og grunden til, at det blev opdaget, var, at han havde brugt en offentlig telefonboks i Los Angeles til at lave sine spillemæssige satsninger. FBI havde optaget telefonsamtalen med en elektronisk optager, der var

4 Paragraf 4 lyder i sin fulde ordlyd således: "The right of the people to be secure in their persons, houses, papers, and effects, against unreasonable searches and seizures, shall not be violated, and no Warrants shall issue, but upon probable cause, supported by Oath or affirmation, and particularly describing the place to be searched, and the persons or things to be seized. 
monteret på telefonboksens yderside. Sagen gik som sagt hele vejen til højesteret, som besluttede, at Paragraf 4 beskyttede retten til privatliv, også i det offentlige rum. I højesterets konklusion stod bla. følgende:

- Så længe et individ med en vis rimelighed kan forvente, at hans samtale forbliver privat, så er hans eller hendes samtale beskyttet mod "urimelig aflytning og registrering"

- Paragraf 4 beskytter mennesker, ikke steder. Derfor kan et individs rettigheder ikke overtrædes, uanset om der er tale om fysisk 'indbrud' i et givet område ${ }^{5}$

Efter 9/11 har lovgivningen ændret sig, men den lovgivning, som SCP refererer til, er på mange måder hypermoderne, ikke mindst i sin understregning af, at paragraf 4 beskytter mennesker og ikke steder. Det var ikke, fordi Katz var i en telefonboks (dvs. inden for et afgrænset sted), at hans rettigheder var beskyttet, men fordi han var i en situation, hvor han med rimelighed kunne forvente, at hans samtale ville forblive privat.

For at afgøre, om han med rimelighed kunne forvente dette i situationen, er det nødvendigt at afkode og fortolke situationen. Grænsen mellem det private og det offentlige kan ikke afgøres med henvisning til en fysisk afgrænsning. På denne måde er den gamle højesteretsdom moderne i Gilles Deleuzes' forstand. Den anerkender implicit, at vi ikke lever i det, som Foucault kalder disciplinære samfund med institutionelt definerede regulationer, men at enhver regulation må medkalkulere individets mobilitet.

Ved første øjekast synes SCPs optræden gammeldags, ikke bare i deres performancestil, men også i deres tematiske udgangspunkt for at forstå overvågning. Deres meget direkte henvisninger til George Orwells billede af BigBrother antyder, at de ser nutidens overvågning som beslægtet med Big Brothers overvågning i det totalitære samfund i bogen 1984. Ser man imidlertid på deres komplekse iscenesættelse af 1984, så er deres pointe med at henvise til 1984 ikke at sige, at vi lever i et totalitært samfund, men at den måde, som overvågningskameraerne fungerer på, tilhører en logik, der kommer fra det disciplinære samfund. SCP's bevidste ironiske iscenesættelse udstiller ikke blot deres egen amatøragtige primitivisme, men udstiller også kameraernes potentielt anakronistiske udsigelsesposition.

5 Teksten lyder på engelsk: 1). So long as an individual can justifiably expect that his conversation would remain private, his/her conversation is protected from "unreasonable search and seizure" by the Fourth Amendment. 2). The Fourth Amendment protects people, not places. Therefore, the rights of an individual may not be violated, regardless of whether or not there is physical intrusion into any given area. 3). A warrant is required before the government can execute a wiretap, and the warrant must be sufficiently limited in scope and duration. 


\section{Dividualer og eksistentiel teknologi}

Både Tracking Transience og 1984 arbejder med radikal åbenhed og ironi som en modstrategi til overvågning. I begge værker rejses der gennem en ludisk, dialogisk strategi spørgsmål til overvågningens objektive neutralitet. Der gøres i særlig grad opmærksom på den situation, det overvågede menneske står i, og ikke mindst de politiske eller generelt eksistentielle ubehageligheder, den overvågede kan blive udsat for. Hvis man vil forstå overvågningens konsekvenser også for det almindelige individ, så er man nødt til at analysere, hvilke konsekvenser den generaliserede observation og objektgørelse har for individets selvforståelse. Som Norman Bryson skriver, så er der bag enhver visuel oplevelse også en social og normativ ide om visualitet:

"Mellem subjektet og verden indsættes hele summen af diskurser, som udgør visualiteten, den kulturelle konstruktion, og som gør visualiteten anderledes end visionen, begrebet om umiddelbar og umedieret synsmæssig erfaring. Mellem nethinden og verden er der indsat en skarm af tegn, en skærm bestående af alle de forskelligartede diskurser om syn, som er indbygget i den sociale arena.” (Bryson: 91-92). ${ }^{6}$

Ifølge Bryson kaster denne skærm en skygge over forholdet mellem menneske og verden. I overvågningssituationen bliver det konkrete overvågningsapparat en inkarnation af denne skygge, som består af en historisk indlejret og multifacetteret social dimension.

Denne sociale dimension er med til at determinere forholdet mellem menneske og maskine, og mellem menneske og verden, og dette afficerer også opfattelsen af, hvad subjektet er. Som tidligere nævnt foreslår Deleuze begrebet 'dividual' til at betegne individet som en slags generaliseret modus inden for det sociale. Dividualen er hverken subjekt i traditionel, essentiel forstand eller bare en del af massen, men et sted midtimellem. Overvågningskameraernes teknologi er med til at understrege denne generelle værenstilstand mellem subjektivitet og fortabelse i massen. Denne tilstand kan imidlertid vendes til en positiv pointe, f.eks. i sousveillance-strategierne, sådan som Steve Mann for eksempel har beskrevet det. Han kalder selv sine sousveillance-kameraer for "eksistentiel teknologi”, og det, der kendetegner en sådan teknologi, hævder Mann, er, at den "bemyndiger [empover] subjektet ved at fjerne bemyndigelse og ansvar fra [by disempowering the individual of responsibility] subjektet for hans eller hendes handlinger.” (Mann 2003: 19).

Hvad enten disse mellemtilstande vurderes som positive eller negative, så er der i overvågningsteknologierne og i refleksionen over dem i overvågnings-kunstværker, en interessant forhandling mellem det humane og det inhumane, som på langt sigt 
måske også kan rokke ved den juridiske forståelse af forholdet mellem det private og det offentlige.

\section{Surveillance: en ny form for lovgivning}

Der er imidlertid en anden konsekvens, som det i denne artikel er mere interessant at forfølge, fordi den siger noget mere specifikt om overvågningens situation i dag. Som tidligere nævnt, så skal man ikke kun vurdere overvågningen på omfanget af kameraer mv., men især på, hvordan informationerne samles, efter hvilke kriterier de vurderes, og hvad de efterfølgende anvendes til. I de to analyserede kunstværker er det politi- og efterretningsvæsen, der er overvågningens handlende subjekt, men begge disse instanser handler på vegne af loven. Jeg har også delvist aftegnet det lovmæssige grundlag for overvågningen i begge de to tilfælde.

I videre forstand rejser de to værker imidlertid også spørgsmålet om forholdet mellem lovgivning og overvågning. Man kan nemlig spørge, i hvor høj grad loven kan indfange og regulere den massive og komplekse overvågning, der finder sted $\mathrm{i}$ dag, eller hvorvidt overvågningen måske har løsrevet sig fra sin lovgivningsmæssige sammenhæng.

Dette spørgsmål rejses som nævnt i artiklen, “Global Panopticism” fra 2008 af juristen Larry Catá Backer. Backer hævder i denne artikel, at overvågningen er udtryk for en grundlæggende frakturering af samfundet, som ganske vist følger en ganske bestemt logik, men som ikke inddæmmes af almindelig lovgivning. Han skriver:

"Overvågning er en ny form for lovgivning, gennem hvilken gamle grænser mellem det offentlige og det private, det nationale og det transnationale, er gjort irrelevante. Konstruktionen af komplekse systemer af bevidst og permanent synlighed, som både normative systemer og bundter af specifikke teknikker, påvirker magtrelationerne mellem stater, økonomiske enheder og individer. Det repræsenterer modaliteter af frakturer og komplikationer i udøvelsen af den regulative magt, som gentager (replicate) sine former og effekter i hele samfundet.” (Backer: 105) ${ }^{7}$

Den moderne udvikling har ændret overvågning fra at være en nogenlunde passiv funktion til at være en aktiv del af det generelle normative system, der regulerer vores adfærd. Overvågningselementet tydeliggøres af teknologiske maskiner (specielt er overvågningskameraerne meget tydelige og bastante, selvom de også i stigende grad camoufleres som lamper og dekorative elementer), men disse maskiner skal ikke forstås som identisk med overvågningssystemet. Det normative overvågningssystem er således diffunderet ud i en lang række af praksisser, der rækker ud over

7 Citatet lyder på engelsk: "Surveillance is a new form of lawmaking through which the old boundaries between the public and private, national and transnational, are made irrelevant. The construction of complex systems of conscious and permanent visibility, as both normative systems and bundles of specific techniques, affects the power relationships among states, economic entities, and individuals. It represents modalities of fractures and complications in assertions of regulatory power, replicating its forms and effects throughout society". 
almindelig lovgivning, og som er med til at opløse en generel skelnen mellem det private og det offentlige. Overvågning har således ifølge Backer udviklet sig fra at være et eksempel på governance til at være basis for governance. Overvågning, dvs. begæret om at synliggøre, overskue, evaluere, kontrollere, styre mv., er på utallige måder blevet en generaliseret virkemåde i det sociale felt.

Det er også i denne forstand, at man skal afkode de totaliserende elementer i de to kunstværkers diagnose af overvågning. Ingen af værkerne siger, at vi lever i et totalitært samfund à la 1984, men begge værker henviser til 1984 for at gøre opmærksom på, at de konkrete overvågningssituationer, de hver især dokumenterer, er symptomer på en langt større udvikling: den generaliserede overvågningslogik, som styrer social udveksling, som del af en generaliseret regulativ effekt.

Både Elahis værk og SCP's værk arbejder med individer i bevægelse. Elahi registrerer transnationale bevægelser, SCP registrerer de rejsendes bevægelser på en metrostation, og deres teaterstykke har samme flygtighed som disse rejsendes måde at bevæge sig på. Mobiliteten indfanges tilsyneladende af overvågningen, men mobiliteten fungerer også som en udfordring til overvågningen, hvilket ironisk udstilles i de to værker. Ligeledes tematiserer begge værker forholdet mellem det private og det offentlige. Selv om det i begge værker eksplicit handler om at forsvare det private, så rejser værkerne også spørgsmålet om, hvorvidt disse grænser mellem det private og det offentlige kan findes, og hvor de kan findes. De to værker skal ikke bare ses som et forsvar for privatlivet og som et angreb på det offentliges angreb på dette, men snarere som et forsvar for at se forholdet mellem det private og det offentlige som et forhold, der er dynamisk, medieret og altid situeret - hvis altså kunsten kan siges at forsvare noget.

Overvågningskunsten synliggør og reflekterer først og fremmest nogle af de grundlæggende modsætningsforhold, der er indbygget i overvågningsfænomenet, dvs. f.eks. spændingsfeltet mellem en disciplinær og hypermoderne virkelighed, de uklare grænser mellem det private og det offentlige, samt de mange (fortolknings-) niveauer, der komplicerer og situerer selve overvågningssituationen.

\section{LITTERATURLISTE}

Backer, Larry Catá, "Global Panopticism: States, Corporations, and the Governance Effects of Monitoring Regimes”, Indiana Journal of Global Legal Studies, Vol. 15, 2008, Indiana School of Law: 101-48.

Baumgärtel, Tilman, “Surveillance Camera Players - George Orwell's 1984”, interview med Bill Browne, repræsentant for Surveillance Camera Players, in Thomas Levin et. al. (eds), CTRL space, Cambridge Mass, London UK: 616-19.

Beck, Ulrich, Risikosamfundet. På vej mod en ny modernitet, Kbh: Gyldendal, 1997 (Frankfurt a. M: Suhrkamp, 1986). 
Bryson, Norman, "The Gaze in the expanded Field”, Hal foster, Vision and Visuality. Discussions in Contemporary Culture, New York: The New Press, 1988: 87-113.

Deleuze, Gilles, Foucault, Paris: Minuit, 1986.

Deleuze, Gilles, "Postscript on Control Societies" in Thomas Levin, Ursula Frohne and Peter Weibel (eds), CTRL Space. Rhetorics of Surveillance from Bentham to Big Brother, Cambridge, Mass, London, UK: The MIT Press, 2002: 316-21.

Deleuze, Gilles. "Postscriptum om kontrolsamfundet" ["Post-scriptum sur les sociétés de contrôle", 1990], oversat af Karsten Gam Nielsen og Adam Diderichsen. Forhandlinger 1972-1990. Frederiksberg: Det lille Forlag, 2006: 212-18.

Druckney, Timothy, “Secret Agents, Security Leaks, Immune Systems, Spore Wars...” in Thomas Levin et. al. (eds), CTRL Space. Rhetorics of Surveillance from Bentham to Big Brother, Cambridge/Mass, London UK: MIT Press, 2002: 150-57.

Haggerty, Kevin D. and Richard V. Ericson, "The Surveillant Assemblage”, British Journal of Sociology Vol. no. 51, No. 4 (December 2000: 605-22).

Haggerty, Kevin D. and Amber Gazso, "Seeing Beyond the Ruins: Surveillance as a Response to Terrorist Threats", The Canadian Journal of Sociology, vol. 30, no, 2, Spring 2005: 169-87.

Levin, Thomas Y, Ursula Frohne, and Peter Weibel, CTRL Space. Rhetorics of Surveillance from Bentham to Big Brother, Cambridge, Mass, London, UK: The MIT Press, 2002.

Lyon, David, Surveillance Society. Monitoring everyday life, Buckingham, Philadelphia: Open University Press, 2002 (2001).

Lyon, David, Theorizing Surveillance. The Panopticon and beyond, Devon/Oregon: Willan Publishing, 2006.

Mann, Steve, “"Reflectionism” and "Diffusionism”: New Tactics for Deconstructing the Vide Surveillance Superhighway" i Thomas Levin et. al. (red.), CTRL Space. Rhetorics of Surveillance from Bentham to Big Brother, Cambridge, Mass, London, UK: The MIT Press, 2002: 531-43.

Mann, Steve, “Existential Technology: Wearable Computing Is Not the Real Issue!”, Leonardo, Vol. 36, No. 1: 19-25. 2003.

Mortensen, Henning, Erik Valeur og Pernille Tranberg, De overvågende. Debatbog om privacy og løsningsmodeller, Kbh: Book son Demand GmbH, 2009.

"PHR2006 - Kingdom of Denmark", en oversigtsrapport, lavet af Privacy International om lovændringer i Danmark fra 2000-2007, der har øget overvågningen på en række områder, se: <http://www.privacyinternational.org/article.shtml?cmd[347]=x-347-559545>, 31. maj, 2010.

“The 2007 International Privacy Ranking” Privacy International d. 28. 12, 2007 og kan ses på følgende hjemmeside: <http://www.privacyinternational.org/article. shtml?cmd[347]=x-347-559597>

The Military Order of November 13, 2001. Detention, Treatment and Trial of Certain Non-Citizens in the War Against Terrorism".

USA Patriot Act:"Uniting and Strengthening America by Providing Appropriate Tools Required to Intercept and Obstruct Terrorism Act”. PUBLIC LAW 107-56-OCT. 26, 2001, <http://frwebgate. access.gpo.gov/cgi-bin/getdoc.cgi?dbname=107_cong_public_laws\&docid=f:publ056.107.pdf> (En opsummering af de vigtigste punkter er lavet af The Library of Congress på <http://thomas. loc.gov/cgi-bin/bdquery/z?d107:HR03162:@@@Dsumm2=m\&>, 31. maj, 2010.

Zuckerman, Ethan, "Tracking Hasan Elahi” 19. okt, 2006. <www.worldchanging.com/ arhcives/005105,html>, 27. maj 2010. 